\title{
STRATEGI PENDIDIKAN MANAJEMEN TRANSPORTASI DAN LOGISTIK UNIVERSITAS MARITIM AMNI SEMARANG DALAM MENGHADAPI TANTANGAN GLOBAL
}

\author{
Kusdibyo $^{1^{*}}$ \\ ${ }^{1}$ Universitas Maritim AMNI Semarang \\ *Email : kusdibyo86@gmail.com
}

\begin{abstract}
Abstrak
Menghadapi tantangan Era Globalisasi dan Kesiapan memasuki era Asean Economic Community (AEC), pasar ekonomi Indonesia nampaknya ragu. Karena ketersediaan tenaga ahli di bidang Transport dan Logistik masih sangat memadai, salah satu tantangan terberat yang dihadapi pasar terbuka Asean adalah pemanfaatan tenaga ahli di bidang Transport dan Logistik. Oleh karena itu, Universitas Maritim Amni Semarang menjawab tantangan dunia bisnis Transportasi dan Logistik dalam penyelenggaraan pendidikan untuk menciptakan kurikulum pendidikan ahli logistik yang handal dan bereputasi global yaitu dengan mewujudkan Universitas Maritim Amni Semarang. memaparkan kondisi pendidikan di Indonesia ditinjau dari segi kualitas, outcome yang dihasilkan, kesesuaian outcome dengan dunia kerja serta menggali informasi tentang karakteristik tenaga kerja potensial yang siap terjun dalam "MEA". Penelitian ini merupakan penelitian deskriptif kualitatif dengan pengumpulan data berupa observasi, studi literatur dan dokumentasi. Hasil dari penelitian ini adalah Transformasi pendidikan diperlukan agar pendidikan mampu menghasilkan SDM yang handal dan tangguh; pendidikan dan tenaga pendidik harus ditingkatkan (kualitasnya sebagai pendidik diiringi dengan memberi kesejahteraan bagi pendidik ditata secara profesional). MEA menuntut tenaga-tenaga kerja yang terampil dan profesional.
\end{abstract}

Kata kunci: Pendidikan manajemen, kurikulum, transportasi, logistik, tantangan global

\section{PENDAHULUAN}

Dalam pengelolaan SDM, Indonesia masih sangat jauh tertinggal dengan negara tetangga seperti Malaysia, Thailand, Filipina, dan negara lainnya. Hal ini disebakan oleh tingkat pendidikan Indonesia masih rendah dan fasilitas yang tidak memadai sehingga mengakibatkan kualitas tenaga kerja yang rendah, pengangguran meningkat, produktivitas menurun, serta daya saing rendah untuk mampu menghadapi persaingan diantara tenaga kerja baik dari dalam negeri maupun di luar negeri. Indonesia dengan kesembilan negara anggota ASEAN lainnya sudah menandatangani deklarasi blueprint Masyarakat Ekonomi Asia (MEA) untuk memulai suatu langkah integrasi dari segi ekonomi. Hal ini membuat Indonesia harus berusaha memperbaiki kualitas SDM (SDM) serta meningkatkan standar kompetensi tenaga kerja Indonesia agar mampu bertahan ditengah era perdangan bebas yang akan datang. Pemerintah
Indonesia harus bisa fokus dan peduli pada masalah tenga kerja dan segera berbenah untuk menciptakan iklim yang kondusif untuk mempercepat gerakan pertumbuhan ekonomi melalui SDM. Pembenahan tersebut dapat dilakukan dengan peningkatanpendidikan, pemerataan pendidikan, peningkatan kesehatan, melakukan pelatihan kepada tenaga kerja, menyediakan fasilitas yang memadai, pembenahan struktur ketenagakerjaan di Indonesia, dan lain - lain akan mendorong kualitas tenaga kerja. Saat sebuah negara memiliki daya saing yang tinggi dan mampu berkompetisi di kancah regional dan global maka dapat dipastikan tenaga kerja yang dimiliki telah mampu mencapai standarisasi dan memiliki reputasi yang baik yang tentunya akan menguntungkan negara (Kadarisman, et al., 2016). SDM merupakan salah satu faktor kunci dalam reformasi ekonomi, yakni bagaimana menciptakan SDM yang berkualitas dan memiliki keterampilan serta berdaya saing 
tinggi dalam persaingan global yang selama ini kita abaikan. Global yang sudah pasti dihadapi oleh bangsa Indonesia menuntut adanya efisiensi dan daya saing dalam dunia usaha. Dalam global yang menyangkut hubungan intraregional dan internasional akan terjadi persaingan antar negara. Indonesia dalam kancah persaingan global menurut World Competitiveness Report menempati urutan ke-45 atau terendah dari seluruh Negara yang diteliti, di bawah Singapura (8), Malaysia (34), Cina (35), Filipina (38), dan Thailand (40). Dalam hal ini dapat dilihat bahwa Indonesia masih sangat jauh tertinggal dalam persaingan global. Pembangunan bangsa Indonesia ke depan sangat tergantung pada kualitas SDM dan tenaga kerja Indonesia yang sehat fisik dan mental serta mempunyai keterampilan dan keahlian kerja, sehingga mampu dan siap berkompetisi di dalam persaingan global (MEA).

Data bisnis di bidang logistik tumbuh sekitar $15 \%$ - 20\% per tahunnya, dengan total pasar transportasi dan logistik di Indonesia yang sekitar Rp 1.849 triliun. Pemerintah berupaya untuk membuat logistik ini menjadi efisien, terkait masih tingginya biaya logistik nasional yang mencapai 26 persen dari pertumbuhan Produk Domestik Bruto (PDB) nasional. Unimar AMNI Semarang sangat mendukung upaya pemerintah untuk menghasilkan lulusan sebagai tenaga ahli yang handal di bidang transportasi dan logistik dan mempunyai reputasi global dengan siap mencetak tenaga kerja siap pakai (Wibowo \& Chairuddin, 2017). Unimar AMNI Semarang memberikan dukungan dalam menghasilkan SDM yang khusus melahirkan lulusan Manajemen Transportasi dan Logistik. Keberhasilan pembangunan dan kemajuan suatu bangsa ditentukan oleh SDM yang andal. Oleh karena itu, upaya meningkatkan kualitas SDM yang andal dan siap dalam menghadapi tuntutan dan perubahan zaman, harus terus dilakukan agar mampu bertahan dalam persaingan global. Kualitas SDM, salah satunya ditentukan oleh faktor pendidikan, mempunyai peranan yang sangat penting dan strategis dalam menentukan kemajuan dan keberhasilan suatu bangsa. Berbicara mengenai perkembangan Negara Indonesia, pasti tidak bisa lepas menyangkut pendidikan Indonesia di mata dunia. Pendidikan merupakan salah satu faktor penting kewibawaan sebuah negara. Dengan pendidikan yang baik, pastinya akan melahirkan generasi penerus bangsa yang cerdas dan kompeten di bidangnya. Dengan demikian, kondisi bangsa akan terus mengalami perbaikan dengan adanya para penerus bangsa yang mumpuni dalam berbagai lini. Agar memudahkan pemahaman tentang dinamikan pendidikan di Indonesia serta relevasinya terhadap dunia kerja dalam masyarakat global maka tulisan ini mengkaji tentang kesiapan dunia pendidikan di Indonesia dalam menghadapi MEA, dengan beberapa pertanyaan penelitian sebagai berikut: 1) Bagaimana kesesuaian antara lulusan yang dihasilkan dengan tuntutan dunia pekerjaan? 2) Apa esensi transformasi pendidikan agar pendidikan mampu menghasilkan SDM yang handal dan tangguh? 3) Bagaimana tuntutan kualifikasi tenaga kerja menyongsong "MEA"? Adapun tujuan dan manfaat penelitian adalah memaparkan kondisi pendidikan di Indonesia ditinjau dari segi kualitas, outcome yang dihasilkan, kesesuaian outcome dengan dunia kerja serta menggali informasi tentang karakteristik tenaga kerja potensial yang siap terjun dalam "MEA".

\section{LANDASAN TEORI}

Penjelasan Peraturan Pemerintah (PP) Republik Indonesia Nomor 8 Tahun 2011 tentang Angkutan Multimoda (Multimodal Transport) adalah angkutan barang dengan menggunakan paling sedikit dua moda transportasi yang berbeda, atas dasar satu kontrak yang menggunakan dokumen angkutan multimoda dari satu tempat diterimanya barang oleh badan usaha 
angkutan multimoda ke suatu tempat yang ditentukan untuk penerimaan barang tersebut. Angkutan multimoda merupakan komponen penting dari sistem logistik, karena angkutan barang dalam aktivitas logistik pada umumnya menggunakan lebih dari satu moda transportasi. Jasa angkutan multimoda diselenggarakan oleh badan usaha angkutan multimoda. Badan usaha angkutan multimoda tidak semata-mata memberikan layanan angkutan barang dari tempat asal sampai ke tujuan, tetapi juga memberikan jasa tambahan berupa jasa pengurusan transportasi (freight forwarding), jasa pergudangan, jasa konsolidasi muatan, penyediaan ruang muatan, serta pengurusan kepabeanan untuk angkutan multimoda ke luar negeri dan ke dalam negeri. Angkutan multimoda diatur dalam United Nations Convention on International Multimodal Transport of Goods, dan dalam ASEAN Framework Agreement on Multimodal Transport (AFAMT). Peran angkutan multimoda semakin penting dengan adanya agenda integrasi system logistic ASEAN menuju kepada perwujudan pasar tunggal ASEAN. Integrasi sistem logistik ASEAN dan ASEAN Framework Agreement on Multimodal Transport menyiratkan adanya liberalisasi di bidang jasa angkutan multimoda di kawasan ASEAN yang pada akhirnya menuju kepada liberalisasi jasa pada tataran global General Agreements on Tariffs and Trade (GATT's).

Dengan demikian perlu diciptakan iklim yang kondusif bagi berkembangnya badan usaha angkutan multimoda nasional yang tumbuh berkelanjutan dan berdayasaing. Proses logistic pada dasarnya diarahkan untuk mengoptimalkan factor produksi, yaitu untuk melakukan optimasi terhadap biaya, waktu dan kualitas. Penyerahan tepat waktu dan aman dari barang dan orang sangat penting bagi perekonomian dan tekanan untuk memberikan lebih cepat, lebih jauh dan selalu ada ketika dibutuhkan. Oleh karena itu penentuan lokasi sangat mempengaruhi ke ekonomian sistem logistik. Lokasi depo dipengaruhi oleh: Biaya produksi, terutama dalam kaitannya ketersediaan tenaga kerja, upah buruh, bahan bakar, dan daerah produksi, Biaya pergudangan, transshipment dan lokasi penempatan gudang, Biaya untuk melakukan konsulidasi dan dekonsolidasi.

Menurut data Indeks Pengembangan Manusia dari The United Nations Development Program (UNDP) tahun 2011, Indonesia berada di posisi 124 dari 187 negara yang disurvei. Posisi Indonesia berada di bawah Singapore (posisi 26), Brunei (posisi 33), Malaysia (posisi61), Thailand (posisi 103) dan Filipina (posisi112). Peringkat ini dihitung ulang setiap tahun menggunaka data yang terbaru bisa dibandingkan secara internasional dalam bidang kesehatan, pendidikan dan pendapatan. Peringkat Indonesia di posisi tersebut membuktikan bahwa kualitas pendidikan di Indonesia saat ini sangat memprihatinkan. Standar Nasional Pendidikan Tinggi Berdasarkan Permendikbud No.5/2020, Standar kompetensi lulusan merupakan kriteria minimal tentang kualifikas kemampuan lulusan yang mencakup sikap, pengetahuan, danketerampilan yang dinyatakan dalam rumusan capaian pembelajaran lulusan digunakan sebagai acuan utama Pengembangan standar isi pembelajaran, standar proses pembelajaran, standar penilaian pembelajaran, standar dosen dan tenaga kependidikan, standar sarana dan prasarana pembelajaran, standar pengelolaan pembelajaran, dan standar pembiayaan pembelajaran, Mengacu pada KKNI, Rumusan capaian, pembelajaran lulusan sebagaimana dimaksud wajib:

a. mengacu pada deskripsi capaian pembelajaran lulusan KKNI; dan

b. memiliki kesetaraan dengan jenjang kualifikasi pada KKNI

Tingkat kedalaman dan keluasan materi pembelajaran untuk setiap program pendidikan, dirumuskan dengan mengacu pada deskripsi capaian pembelajaran lulusan dari KKNI, Tingkat kedalaman dan 
keluasan materi pembelajaran bersifat kumulatif dan/atau integratif, Tingkat kedalaman dan keluasan materi pembelajaran dituangkan dalam bahan kajian yang distrukturkan dalam bentuk mata kuliah. Dengan demikian, kompetensi menunjukkan keterampilan atau pengetahuan yang dicirikan oleh profesionalisme dalam suatu bidang tertentu sebagai sesuatu yang terpenting, sebagai unggulan bidang tersebut. Kompetensi menyebabkan orientasi pada hasil, kemampuan mempengaruhi orang lain, serta meningkatkan inisiatif.

Peningkatan kompetensi

meningkatkan kinerja bawahan dan kontribusinya pada organisasi akan meningkat. Menurut UNESCO empat pilar tersebut adalah: learning to know, learning to do, learning, to be, dan learning to live together. Untukmenyikapi ini, maka reformasi sistem pendidikan harus dilakukan untuk menjamin peningkatan kualitas pendidikan. Di Indonesia, peran pendidikan dalam membangun martabat dan peradapan manusia masih masih sebatas wacana karena dilihat dari sisi capaian dalam pendidikan masih jauh dari harapan semestinya.

Menurut penelitian terdahulu tentang tantangan dunia pendidikan di dalam mengahadapi era globalisasi, dampak global pada pengelolaan pendidikan global ibaratkan dua sisi keping mata uang yang satu bagian dengan bagian yang lain saling berperan, artinya global telah menyebabkan kemajuan yang luar biasa pada peradaban manusia, namun pada saat yang bersamaan juga tidak sedikit efek negatif yang ditimbulkan dengan datangnya global itu. Kita ambil contoh yang terjadi pada dunia pendidikan saat ini. Adanya global yang ditandai dengan kemudahan dalam mengakses informasi, telah menyebabkan lompatan yang sangat luar biasa. Penemuan-penemuan penting yang tercipta dalam dunia pendidikan seperti metode pengajaran, kurikulum, media dan lain-lain, demikian mudahnya tersebar dalam waktu yang tidak lama bahkan hanya dalam hitungan menit bahkan detik saja. (Efferi, 2015). Dunia yang semakin menyatu dalam satu kesatuan yang utuh melalui global sudah menjadi kenyataan. Saat ini, bukan saja isu perekonomian dan perdagangan dunia yang kian menyatu, namun juga berbagai isu lain, seperti demokratisasi, ilmu pengetahuan, teknologi, komunikasi dan informasi, bahkan pendidikan, serta berbagai isu lainnya. Berbagai negara membentuk aliansi bersama untuk bergabung dalam satu kekuatan besar dalam menghadapi persaingan yang semakin kompetitif. Sehingga batasan suatu negara kian tak kentara dengan tingkat dinamika dan mobilitas yang semakin tinggi dari masyarakatnya.

Sebagai bagian dari masyarakat global, Indonesia menghadapi berbagai macam permasalahan yang kompleks, hal ini merupakan salah satu akibat dari lamanya bangsa ini dikuasai oleh penjajah yang sifatnya eksploratif. Pada masa itu, bangsa ini hanya dimanfaatkan sumber daya alamnya yang melimpah, sedangkan dalam SDMnya dibodohkan dengan berbagai cara, sehingga bangsa ini tidak mengalami masa perkembangan yang menakjubkan dalam bidang ilmu pengetahuan, pendidikan, maupun teknologi. Yulia (2008) memaparkan bahwa dipilihnya Indonesia sebagai pusat perdagangan bebas MEA, maka pemerintah Indonesia perlu untuk melakukan persiapan, mulai dari persiapan infrastruktur sampai kepada persiapan dalam menciptakan SDM (SDM) masyarakat Indonesia yang terampil, mempuni dan professional (Johan \& Tamansiswa, 2014). Saat ini Indonesia menjadi target pasar bagi perusahaanperusahaan global untuk menikmati keuntungan besar, sedangkan perusahaan Indonesia kalah dalam persaingan.

\section{METODE}

Penelitian ini menggunakan pendekatan kualitatif yaitu untuk mengetahui atau menggambarkan 
kenyataan dari kejadian yang diteliti sehingga memudahkan untuk mendapatkan data yang objektif dalam rangka mengetahui dan memahami strategi dalam menghadapai tantangan era global khususnya di bidang pendidikan. Penelitian ini juga menggunakan metode deskriptif. Sumber data utama dalam penelitian ini berupa data primer yaitu hasil wawancara yang diperoleh dari narasumber yang terdiri dari 2 dosen Matakulaih Manajemen Logistik pada prodi Transportasi dan 50 Mahasiswa prodi Transportasi yang dianggap berpotensi dalam memberikan informasi yang relevan, serta observasi.

Selanjutnya data sekunder berupa literatur dan dokumen serta data yang diambil di lapangan dan yang terdapat pada lokasi penelitian berupa bahan bacaan, bahan pustaka, dan laporan-laporan penelitian. Analisis data dalam penelitian ini dilakukan dengan mencari pola, model, tema, hubungan, persamaan, dan makna dari data yang dinyatakan dalam bentuk pernyataan dan tafsiran setelah menggali data dari beberapa orang informan kunci yang ditabulasikan dan dipresentasikan. Hasil pengumpulan data diolah secara manual, direduksi selanjutnya hasil reduksi dikelompokkan dalam bentuk segmen tertentu (display data) dan kemudian disajikan dalam bentuk isi analisis.

\section{HASIL DAN PEMBAHASAN}

Kesesuaian Lulusan dengan Tuntutan Dunia Kerja

Permasalahan SDM di Indonesia menjadi semakin kompleks terindikasi dengan banyaknya lulusan pendidikan formal dari berbagai jenjang yang tidak terserap dalam dunia kerja, disebabkan oleh banyak faktor di antaranya: 1) jumlah penduduk yang semakin hari semakin bertambah; 2) pertumbuhan angkatan kerja lebih besar ketimbang ketersediaan lapangan kerja; 3) ditribusi penduduk antar daerah tidak merata; 4) ketidaksesuaian kompetensi SDM dengan pasar kerja, distribui informasi tentang pasar kerja yang lambat atau timpang, dan tingginya tingkat pengangguran. Kondisi ini menghambat lajunya penyerapan tenaga kerja baik mereka yang berlatar belakang pendidikan rendah, maupun Perguruan Tinggi. Untuk itu, sangat diperlukan strategi pengembangan SDM di Indonesia yang berbasis kompetensi. Dengan demikian, kelulusan mahasiswa dapat sesuai dengan kebutuhan industri dan dibekali dengan pelatihan dan sertifikasi kompetensi (Gambar 1).

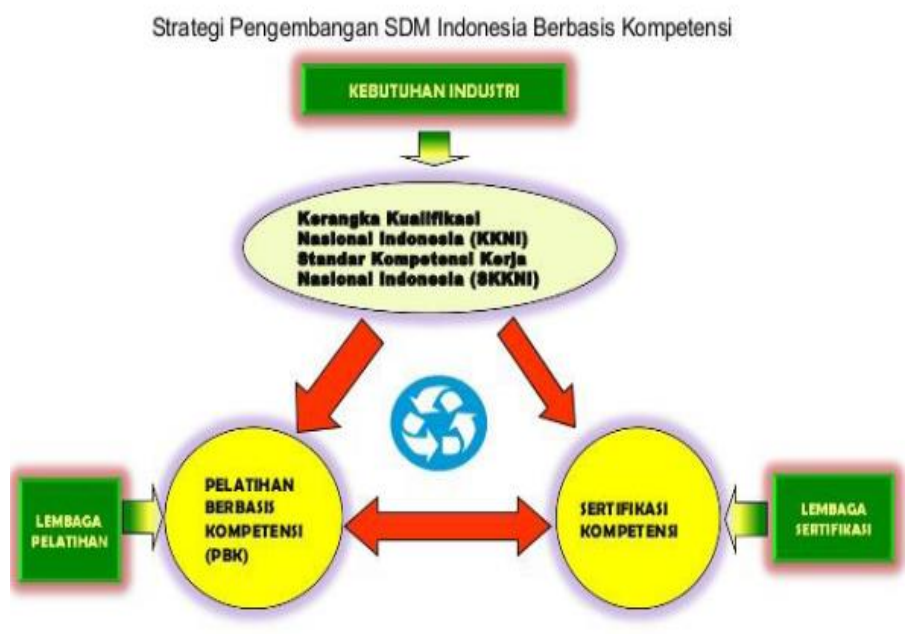

\section{Gambar 1. Strategi Pengembangan SDM Indonesia Berbasis Kompetensi}

Sumber: Departemen Perindustrian

Transformasi Pendidikan dalam Mencetak SDM yang Professional

Transformasi pendidikan di Indonesia adalah sebuah sistem untuk membangun kembali ruh pendidikan di Indonesia agar sesuai dengan tujuan pendidikan nasional di Indonesia. Tujuan pendidikan nasional Indonesia diharapkan mampu melahirkan manusia Indonesia yang religius dan bermoral, menguasai ilmu pengetahuan dan keterampilan, sehat jasmani dan rohani, dan berkepribadian dan bertanggung jawab. Pendidikan abad 21 merupakan pendidikan yang berbasis pada penguasaan pengetahuan, penguasaan keterampilan, serta pembentukan karakter yang unggul. Oleh karena itu pendidikan di Indonesia 
harus sesuai dengan kondisi kehidupan masyarakat abad 21. Oleh karena itu transformasi pendidikan harus ditekankan.

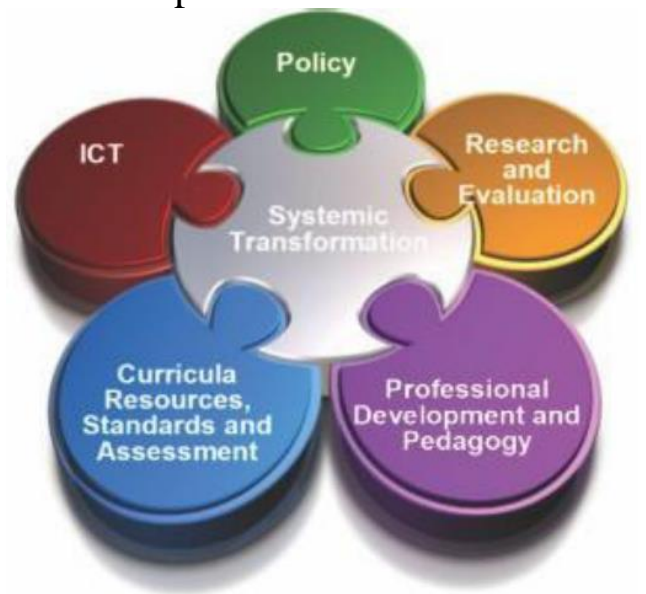

\section{Gambar 2. Pendekatan Sistemik Transformasi Pendidikan}

Transformasi dalam pendidikan Indonesia mencakup: Pendidikan harus mengarah pada pola pembelajaran yang lebih berpusat pada siswa; Pengembangan kompetensi tenaga pendidik, mengubah proses pembelajaran dari tradisional yang berpusat pada Dosen menjadi berpusat pada siswa; Pembelajaran berbasis Teknologi, terjadi integrasi teknologi dalam proses belajar mengajar; Kurikulum, KKNI yang berbasis scientific approach merupakan langkah awal yang tepat dalam meningkatkan kualitas pendidikan di Indonesia agar menghasilkan lulusan yang berkualitas meskipun kurikulum ini masih diperlukan perbaikan-perbaikan terutama pada asesmennya.

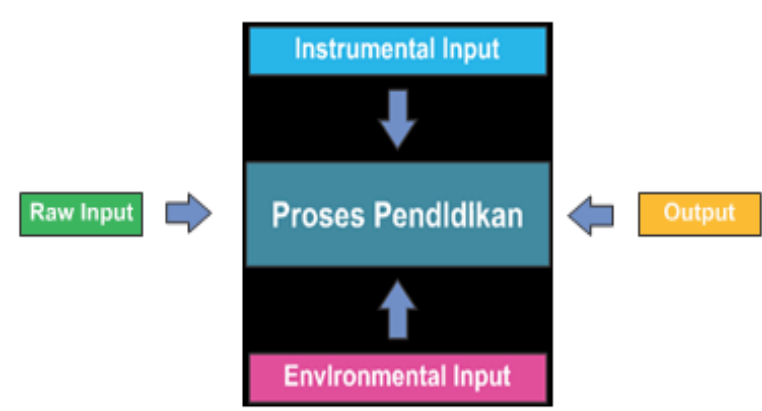

\section{Gambar 3 Proses Transformasi Pendidikan}

Sumber (Satmoko,1996)
Bagan di atas merupakan konsep dari proses transformasi pendidikan. Siswa didik adalah raw input. Selanjutnya raw input ini akan diproses dengan menggunakan model pembelajaran abad 21 dimana siswa adalah pusat dalam proses pembelajaran, dukungan dari instrumental input seperti tujuan pendidikan, sangat berkontribusi ditopang oleh lingkungan yang mendukung seperti keluarga, masyarakat. Sinergi dari instrumental input, environmental input, proses pendidikan terhadap raw input akan menghasilkan output yang berkualitas. SDM yang bermutu hanya dapat diwujudkan dengan pendidikan yang bermutu. Pendidikan bermutu adalah pendidikan yang mampu mengembangkan potensi-potensi positif yang terpendam dalam diri siswa didik. Dengan pendidikan bermutu, pendidikan menghasilkan tenaga-tenaga muda potensial yang tangguh dan siap bersaing dalam masyarakat dunia. Oleh karena itu, upaya peningkatan mutu pendidikan merupakan hal yang tidak dapat ditawar lagi dalam rangka meningkatkan mutu sumber daya bangsa Indonesia.

Pendidikan merupakan proses sistematis untuk meningkatkan martabat manusia secara holistik. Hal ini dapat dilihat dari filosofi pendidikan yang intinya adalah untuk mengaktualisasikan tiga dimensi kemanusiaan paling mendasar, yakni: (1) afektif yang tercermin pada kualitas keimanan dan ketakwaan, etika dan estetika, serta akhlak mulia dan budi pekerti luhur; (2) kognitif yang tercermin pada kapasitas pikir dan daya intelektualitas untuk menggali ilmu pengetahuan dan mengembangkan serta menguasai teknologi; dan (3) psikomotorik yang tercermin pada kemampuan mengembangkan ketrampilan teknis dan kecakapan praktis (Depdiknas, 2005).

Idealisme pada pendidikan mengedepankankan nilai-nilai humanisme yang mendasar sehingga dengan niai-nilai tersebut mampu menbentuk manusiamanusia yang berkualitas. Abad 21 merupakan abad pengetahuan. Oleh karena 
itu, sudah seharusnya pendidikan di Indonesia melangkah seiring dengan tuntutanjaman agar bangsa Indonesia tidak terlindas oleh jaman akibat ketidak berdayaannya. Kualifikasi Tenaga Kerja Menyongsong MEA Banyak pihak masih meragukan bahwa liberalisasi sektor jasa ASEAN seiring dengan diterapkannya Komunitas Ekonomi ASEAN 2015 akan menguntungkan Indonesia, khususnya para pekerja Indonesia. Secara kualitas jumlah tenaga kerja terdidik di Indonesia adalah $33.1 \%$ sedangkan jumlah tenaga kerja kurang terdidik hampir dua kali dari jumlah tenaga terdidik yaitu $66.9 \%$. Ini menunjukkan bahwa secara kualitas SDM Indonesia masih rendah karena tingkat usia kerja berpendidikan rendah masih cukup tinggi.

SDM bukan hanya sekedar mengelola kepentingan karyawan, namun stakeholder. Pengaruh pelatihan dan pengembangan, serta kompensasi terhadap kinerja pegawai, disimpulkan bahwa terjadi tingkat pengaruh yang sangat signifikan bagi kinerja pegawai yang mendapatkan pelatihan dan pengembangan yang diselenggarakan perusahaan, selain konpensasi yang diberikan dan kelayakan serta keadilan dalam pengupahan. Untuk itu, pendidikan pada perguruan tinggi diharapkan mampu menjawab kebutuhan tenaga kerja yang sangat cepat didalam menghadapi tantangan era global yang sangat kompetitif, seperti terlihat pada gambar 4 dimana penyerapan tenaga kerja dari tahun ketahun sangat pesat dikarenakan lulusan perguruan tinggi yang semakin meningkat. Pada tataran perguruan tinggi sertifikasi sangatlah dibutuhkan dan kompetensi juga harus diperhatikan yang bertujuan agar manjedi tenaga kerja yang siap pakai serta professional di bidangnya.

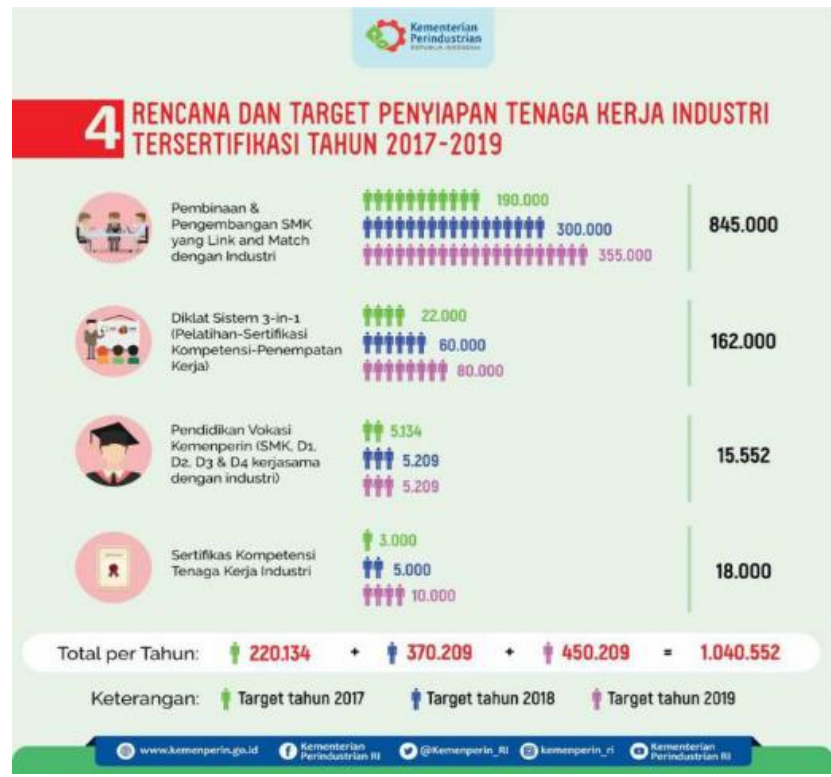

Gambar 4. Target Penyerapan Tenaga Kerja

Sumber Departemen Perindustrian

Indonesia sekarang ini membutuhkan adalah visioning (pandangan), repositioning strategy (strategi), dan leadership (kepemimpinan). Tanpa itu semua, kita tidak akan pernah beranjak dari transformasi yang terus berputar-putar. Dengan visi jelas, tahapan-tahapan yang juga jelas, dan komitmen semua pihak serta kepemimpinan yang kuat untuk mencapai itu. Saran Pendidikan di Indonesia diharapkan dapat mempersiapkan peserta didik menjadi warga negara yang memiliki komitmen kuat dan konsisten untuk mempertahankan Negara Kesatuan Republik Indonesia.

Sebagus apapun konsep perubahan kurikulum, tanpa diimbangi dengan optimalnya peran stakeholder pendidikan, hal itu tidak akan banyak membawa dampak positif bagi kemajuan peradaban bangsa. Sudah terlalu lama bangsa ini merindukan lahirnya generasi bangsa yang "utuh dan paripurna"; berimtaq tinggi, berakhlak mulia, sehat, berilmu, cakap, kreatif, mandiri, dan menjadi warga negara yang demokratis serta bertanggung jawab. Hanya potret generasi semacam ini yang akan mampu membawa bangsa ini sanggup bersaing di tengah kancah peradaban global 
yang demikian kompetitif secara arif, matang, dan dewasa. Nah, akankah perubahan kurikulum di awal tahun ajaran ini mampu menjadi momentum bangkitnya kemajuan dunia pendidikan di negeri kita.

Terkait dengan pelaksanaan rencana strategis, di dalam pelaksanaan perlu diperhatikan beberapa hal di dalam menghadapi pesaing di industri yang sama tentunya kita harus mempunyai diferensiasi atau perbedaan keunggulan dikarenakan banyaknya pesaing yang juga mencoba merebut pasar tenaga kerja di bidang Transportasi dan Logistik. Melakukan kerjasama dengan lembaga-lembaga yang mempunyai kredibilitas didalam mengeluarkan sertifikasi yang akan menjadi modal dan syarat utama mahasiswa di dalam mencari pekerjaan. Sehingga perusahaan besar akan lebih mengutamakan lulusan Universitas Maritim Amni Semarang didalam rekrutmen.

Hal yang perlu diperhatikan juga adalah bekerjasama dengan perusahaan nasional dan internasional untuk menjamin lulusan yang siap bekerja dan dapat langsung ditempatkan di sektor-sektor perusahaan Transportasi dan Logistik. Kemudian memberikan beasiswa kepada mahasiswa baru yang perprestasi dan mahasiswa yang memiliki indeks prestasi komulatif tertingi. Meningktakna sarana dan prasana berskala internasional, meningkatkan SDM yang ada termasuk di dalamnya dosen dan karyawan, agar dapat tercipta meningkatnya mutu dan kualitas pendidikan sehingga dapat menciptakan lulusan terbaik dan siap pakai. Menghadapi tantangan Dengan Era Global tersebut, perguruan tinggi rnenghadapi berbagai tantangan adanya peluang tentunya banyak pula tantangan dan kendala yang akan di hadapi di dalam faktor eksternal mengingat kondisi sekarang tentunya sudah mengalami perubahan yang sangat pesat dibarengi dengan kecanggihan teknologi dan informasi, sehingga harus bekerja keras di dalam menghadapi tantangan, sistim yang baik ditunjang oleh SDM yang mumpuni pasti akan mendapatkan hasil yang baik. Sistim yang terintregitasi juga akan memudahkan di dalam mengurai permasalahan yang dihadapi, dan juga penyesuaian kurikulum. Dunia pendidikan mulai membangun mata rantai dengan dunia kerja/ merespon dunia kerja sehingga lulusan yang dihasilkan sesuai dengan tuntutan dunia kerja; paradigma ini harus dipahami dan dibangun oleh seluruh masyarakat Indonesia.

\section{KESIMPULAN}

Transformasi pendidikan diperlukan agar pendidikan mampu menghasilkan SDM yang handal dan tangguh; pendidikan dan tenaga pendidik harus ditingkatkan (kualitasnya sebagai pendidik diiringi dengan memberi kesejahteraan bagi pendidik ditata secara profesional). MEA menuntut tenaga-tenaga kerja yang terampil dan profesional. Kegiatan-kegiatan keterampilan, kewirausaaan pelatihanpelatihan kerja lebih digalakkan untuk menyokong perbaikan kualitas tenaga kerja yang telah ada. Dari paparan diatas menunjukkan bahwa tuntutan SDM yang terampil dan berkualitas merupakan syarat mutlak agar bangsa Indonesia tidak hanya menjadi pangsa pasar bagi negara-negara ASEAN lainnya namun ikut serta sebagai pelaku utama dalam ajang pasar dunia.

\section{DAFTAR PUSTAKA}

Efferi, A., 2015, Mengelola Lembaga Pendidikan di Era Global (Pergeseran Paradigma Humanis Menjadi Bisnis), Jurnal Pendidikan Islam, Vol. 3, No. 1, pp. 1-19.

Johan, A. B., \& Tamansiswa, F. U. S., 2014, Peran Pendidikan Kejuruan dalam Menghadapi Masyarakat Ekonomi ASEAN (MEA), Journal. Ustjogja. Ac. Id.: 16.

Kadarisman, M., Gunawan, A., \& Ismiyati, I., 2016, Kebijakan Manajemen Transportasi Darat dan Dampaknya Terhadap Perekonomian 
Masyarakat di Kota Depok, Jurnal Manajemen Transportasi \& Logistik, Vol. 3, No. 1.

Simbolon, F., 2013, Strategi Pemasaran Global Di Indonesia, Binus Business Review. Vol. 4, No. 1, pp. 405-413.

Wibowo, W., \& Chairuddin, I., 2017, Sistem Angkutan Multimoda Dalam
Mendukung Efisiensi Biaya

Logistik di Indonesia, Jurnal Manajemen Transportasi dan Logistik, Vol. 4, No. 1, pp. 25-38.

Yulia, 2008, Membangun Daya Saing Bangsa Melalui Pendidikan: Refleksi Profesionalisme Dosen Di Era Global Yulia, Tarbiyah Al Awlad Vol 4, pp. 435-444. 